\title{
To what extent does organic farming promote species richness and abundance in temperate climates? A review
}

\author{
Karin Stein-Bachinger (D) - Frank Gottwald • \\ Almut Haub • Elisabeth Schmidt
}

Received: 30 August 2019 / Accepted: 10 January 2020 / Published online: 1 February 2020

(C) The Author(s) 2020

\begin{abstract}
The loss of biodiversity in agricultural landscapes has been dramatic over the past few decades with negative trends persisting. Organic farming has received widespread recognition in the scientific and politic fields for its environmental benefits, although the proportion of land cultivated organically is still small and the extent to which organic farming contributes to the promotion of biodiversity is viewed controversially. We present a critical, quantitative review of 98 mainly peer-reviewed papers selected from 801 studies in temperate climate zones published over the period 1990-2017. We quantified differences in the species richness and abundance of selected flora and fauna groups. In total, 474 pairwise comparisons that compared organic and conventional farming systems were considered. Overall, organic farming showed higher species richness or abundance in $58 \%$ of the pairs. No differences were found for $38 \%$, $4 \%$ indicated negative effects from organic farming. The average (median) species numbers of flora on arable land were $95 \%$ higher under organic management as well as $61 \%$ higher for seedbank and $21 \%$ higher for field margin vegetation. For field birds, the species richness was $35 \%$, and the abundance was $24 \%$ higher
\end{abstract}

Electronic supplementary material The online version of this article (https://doi.org/10.1007/s13165-020-00279-2) contains supplementary material, which is available to authorized users.

K. Stein-Bachinger $(\bowtie) \cdot$ F. Gottwald $\cdot$ A. Haub •

E. Schmidt

Leibniz Centre of Agricultural Landscape Research, 15374 Müncheberg, Germany

e-mail: kstein@zalf.de in organic farming; for insects, the corresponding values are $22 \%$ and $36 \%$ and for spiders $15 \%$ and $55 \%$. Our study underlines that organic farming can play an effective role in acting against the loss of biodiversity. Future research should focus on the combined effects of landscape structures and organic farming, the effect of largescale organic farming, as well as on the correlation of species diversity and production parameters. To meet the systems' representativeness, even more strict selection criteria need to be applied in further analysis.

Keywords Farming systems · Biodiversity . Comparison $\cdot$ Flora $\cdot$ Fauna $\cdot$ Agricultural management

\section{Introduction}

Agricultural land use has a key role to play in the preservation of wild flora and fauna and their habitats (Firbank 2005). Species groups such as arable flora depend on tillage operations, and field birds live partly on fields that are cultivated for human nutrition and fodder production. Insects play a crucial role, e.g., in pollination and biological pest control. To prevent the alarming decline of biodiversity worldwide, the Biodiversity Convention was agreed at the UN Summit in Rio de Janeiro in 1992 (CBD 2000). However, the loss of biodiversity has continued to accelerate worldwide, and no reversal of this trend can be observed (Pe'er et al. 2017; Pimm et al. 2014). The national indicator for biological diversity in agrarian landscapes in Germany 
shows a continuously negative trend (BMU 2018). Many of the characteristic arable plant species have declined dramatically over the last 30 years (Meyer et al. 2013). Only up to five species can be found in the center of many conventional arable fields (Batáry et al. 2012; Krauss et al. 2011; Gabriel et al. 2010). Those species groups still occurring are depleted and indicate a huge decline in specialized taxa as well as an increase in herbicide-resistant generalists (Heap 2014). The loss of arable flora has far-reaching consequences for biodiversity on arable land, as arable flora forms the basis of food reserves and shelter for insects, birds, brown hares, and other wild animals (Holzschuh et al. 2007). Moreover, the loss of flowering plants affects useful insects and has negative effects on predatorprey relationships (Krauss et al. 2011). Significant losses in the biomass of flying insects (more than $75 \%$ ) are observed by Hallmann et al. (2017). Bird species that depend on small insects and spiders during the breeding period show a loss of about one third over the last 25 years (Wahl et al. 2015). Hooper et al. (2012) argue that the large net losses of biodiversity potentially harm ecosystem functions and services in many regions. In a global assessment, Newbold et al. (2016) estimate that land-use and related pressures have already reduced local biodiversity intactness beyond its proposed planetary boundary across $58.1 \%$ of the world's land surface, where $71.4 \%$ of humans live.

Biodiversity in agrarian landscapes is highly influenced by the kind of land use (Stoeckli et al. 2017; Gabriel et al. 2010; Tscharntke et al. 2005). Diverse crop rotations, the changes of spring and winter crops, including perennial fodder crops, improve the habitats for many wild species, as agricultural management takes place at different times so that there are alternatives during tillage or harvest (Gottwald and SteinBachinger 2016; Stein-Bachinger and Fuchs 2012). Heterogeneous agricultural landscapes encourage diverse species groups and their different ecosystem services (Landis 2017; Tscharntke et al. 2005).

One of the main reasons for the high loss of species and their habitats is intensive land use (Habel et al. 2019; Haber 2014; Uchida and Ushimaru 2014; Benton et al. 2003) with a high input of nutrients and pesticides (Isbell et al. 2013; Meehan et al. 2011), narrow crop rotations (Robinson and Sutherland 2002; Kremen et al. 2002), the reduction of set-asides (Flade 2012; Herzon et al. 2011; Tscharntke et al. 2011) and permanent grassland (Eglington 2009), the removal of landscape elements (Fabian et al. 2013), effective harvesting methods and seed cleaning (McCracken and Tallowin 2004), as well as melioration or set-aside of extensively used habitats (Uchida and Ushimaru 2014; Berg et al. 2004). The loss of wild flora and fauna species has negative effects on subsequent parts of the food chain (Heldbjerg et al. 2016; Krauss et al. 2011). Moreover, the quality and function of agricultural land as a habitat declines as reproduction conditions are degraded (e.g., the loss of suitable breeding sites in dense vegetation) (Quinn et al. 2016; Eglington 2009).

Several reviews and meta-analyses over the last 30 years have shown the positive effects of organic farming on above- and belowground biodiversity in comparison to conventional farming (e.g., Tuck et al. 2014; Rahmann 2011; Mondelaers et al. 2009; Bengtsson et al. 2005; Hole et al. 2005; Azeez 2000; Stolze et al. 2000). These include, e.g., soil microbial abundance and activity (Lori et al. 2017), the diversity of arthropods (Lichtenberg et al. 2017), arable flora (Campiglia et al. 2018; Rydberg and Milberg 2000; Hald 1999; Frieben 1990), and field birds (Chamberlain et al. 1999; Lokemoen and Beiser 1997). Hole et al. (2005) and Rahmann (2011) conducted a qualitative evaluation and emphasized the positive effects of organic farming on biodiversity. Bengtsson et al. (2005) concluded in a quantitative meta-analysis that the richness of the investigated species groups increased by $30 \%$ under organic management and their abundance by $50 \%$ on average. Further comparative studies such as Mondelaers et al. (2009) mostly confirm the positive effects of organic farming on biodiversity through the results of Hole et al. (2005) and Bengtsson et al. (2005). Tuck et al. (2014) conclude in a similar way to Bengtsson et al. (2005) that organic management increases species richness by $30 \%$ and this effect has been robust for the last 30 years. They analyzed 94 studies based on the results of Bengtsson et al. (2005) and further comparative studies, which were published before 2011 .

Organic farming is seen as a land use system that strives to minimize negative environmental impacts such as the loss of biodiversity, nutrient leakage, and soil degradation (e.g., Lori et al. 2017). Although there is strong evidence that organic farming can reduce the negative impacts of land use, the positive effects on biodiversity are viewed controversially (Seufert and Ramankutty 2017; Hodgson et al. 2010). A relatively small proportion of land up to now has been certified organic in the European Union. From 2000 to 2016, a growth of $2.7 \%$ to $6.7 \%$ was noted within the European Union (EU 28) (EUROSTAT 2018). 
But it has to be noticed that especially in developing countries traditional farming methods, which have evolved through generations on many small farms coupled with the non-availability of fertilizers and pesticides, are still applied and these farms remain uncertified although they could be recognized as organic.

In our study, we present a new quantitative and statistically verified assessment of the impacts of conventional and organic farming based on species groups of flora and fauna which are significant for agricultural landscapes. The work was part of the interdisciplinary study on the "Benefits of organic farming for the environment and society" (Sanders and Hess 2019, eds.) which gives a comprehensive analysis and evaluation of scientific studies on public goods provided by organic farming in temperate climate zones since 1990 (with respect to water protection, soil fertility, biodiversity, climate protection and adaptation, resource efficiency, and animal welfare). Here, we present an extended data set to quantify the effects of organic and conventional farming systems on species richness and abundance. We focus on arable flora, seedbank, field margin flora, insects, birds, and spiders based on 98 studies.

\section{Materials and methods}

\section{Data sources and selection criteria}

We compiled data from studies that compared organic and conventional farming systems concerning their impact on species richness and abundance of selected species groups. Organic farming was exclusively defined by the authors in accordance with national and international regulations (European Union Guideline Council Regulations (EC) No 834/2007 on organic production and labelling). For conventional systems, we included studies defined as conventional or integrated farming, taking into account that this represents a range of conventional systems that use synthetic nitrogen fertilizer and pesticides in differing intensities.

Initially, an evaluation of previous reviews and metaanalyses was compiled by screening the selection procedures and criteria, the involved species groups, as well as the indicators, references, and results. Subsequently, a comprehensive literature search was conducted to identify relevant studies addressing the impact of organic and conventional farming systems based on defined criteria (Fig. S1). We systematically searched ISI Web of Knowledge and Scopus using the following keywords including synonyms and using truncations: "organic (ecological, biological) farming (agriculture, management)", "conventional (integrated, nonorganic)", "biodiversity (species diversity, richness, nature conservation, nature protection)", "genetic resources (diversity)" and "rare species".

In total, we identified 1112 studies in the online databases Web of Science and Scopus (core collection) according to the above mentioned keywords. After duplicate checking (Fig. S1), we preselected 801 studies for the analysis, including 89 eligible publications which came from an additional search in the database organic eprints, conference proceedings, or reference lists of reviews and meta-analyses. The studies which were finally selected for quantitative analysis had to meet the following criteria (Sanders and Hess 2019, eds.): (i) publication period, January 1990 to July 2017; (ii) region, temperate climates (all C-climates, Dfa, Dfb, Dwa, Dwb, BSk) according to the Köppen-Geiger climate classification (Kottek et al. 2006); (iii) study design, at least one organic vs. conventional pair with at least three independent replications; and (iv) language, studies in English or German. We evaluated specific flora species groups (arable flora, seedbank, field margin flora), birds, flower-visiting insects, beetles, and spiders.

We have put a focus on the indicators species richness and abundance as the most frequently measured indicators for generating a sufficient and consistent data set for analysis. Due to the very small number of usable results, we excluded the topics "genetic resources" and "rare species" from further evaluation. Species richness is defined as the number of species, whereas abundance stands for the number of individuals of a certain species or species group per unit area and the cover of plants, respectively. Other measures for biodiversity, such as the Shannon-Wiener Index or Evenness, are calculated from the two selected indicators and have been used comparatively rarely in the studies. We analyzed mean and total values separately, whereas mean richness or abundance stands for the mean number of species or individuals per sampling unit (e.g., plot) and total richness or abundance for the sum of collected species or individuals in the investigation area (e.g., farm). In some cases, more than one organism group was investigated in a study, or the recordings were carried out in various crop types. These were analyzed as separate observations.

In order to perform a quantitative evaluation, the studies had to contain extractable data that quantify the effects of the farming system on at least one of the two indicators. We concentrated on measured results, i.e., model-based 
studies were excluded. If the results had been published more than once, the publication with the latest or most complete data set was used. Furthermore, we excluded studies carried out in rice cultivation, aquaculture, or greenhouses as well as bacteria, yeast, fungi, aphids, and hypogeal organisms. Studies investigating the effects of conversion to organic farming were also excluded (Fig. S1).

\section{Data extraction and analyses}

Data were extracted directly from the text, tables, or supplements, where possible. When data were provided graphically, the online tool WebPlotDigitizer (Rohatgi 2018) was used for standardized data extraction. As methods of data collection varied greatly among studies even for the same parameter, extracted values were not directly comparable. Therefore, the relations between organic and conventional farming (\%) were calculated for each pair (conventional variant $=100 \%$ ). The percentage deviation ${ }^{1}$ between organic and conventional farming was graphically illustrated using boxplot diagrams, if at least nine pairs were available. Statistics (minimum, maximum, quartiles) were calculated. Based on the difference, the effect of the organic variant was classified for each individual pair: organic + (species richness or abundance were higher in organic farming), organic $=$ (no impact of the farming system), and organic $-($ species richness or abundance were lower in organic farming) (Sanders and Hess 2019, eds.). If information on the significances of the results was given in the studies, we used this for evaluation. If no significances were shown, a deviation of at least $20 \%$ of the organic variant to the conventional variant was applied. This conservative classification for "no impacts" was chosen due to the methodological variations used in field experiments.

\section{Results}

General data evaluation

In total, we included 98 studies (S2) with 474 pairwise comparisons (experimental fields and farm comparisons) from 21 countries (Table 1). About 91 studies originated from peer-reviewed scientific journals and 7 studies from the additional search. All of the studies met the criteria mentioned above.

\footnotetext{
$\overline{1}$ [indicator value org] - [indicator value con] / [indicator value con] * 100
}

Table 1 Overview of the studies obtained for flora and fauna species groups (1990-2017)

\begin{tabular}{lrrrrr}
\hline & Total & Flora $^{1}$ & Birds & Insects $^{2}$ & Spiders \\
\hline Number of studies & 98 & 45 & 18 & 46 & 18 \\
Number of pairwise & 474 & 147 & 57 & 214 & 56 \\
$\quad$ comparisons & & & & & \\
Coverage of continents & 5 & 2 & 4 & 4 & 3 \\
Coverage of countries & 21 & 11 & 11 & 15 & 9 \\
\hline
\end{tabular}

${ }^{1}$ Arable flora, seedbank, and field margin flora

${ }^{2}$ Flower-visiting insects (e.g., bees, hoverflies, butterflies) and beetles

Effects of organic and conventional management on flora and fauna diversity

In $58 \%$ of the studies analyzed, organic farming increased flora and fauna species richness and abundance (Table 2); for $63 \%$ of these pairs, significant values were given. According to our classification, no differences were found for $38 \%$ of the comparison pairs. In 6 studies (17 pairs) out of 98 , conventional management proved more advantageous (4\%).

Differences between organic and conventional farming for mean richness of flora and fauna species groups are presented in Fig. 1 and Table 3. With regard to the investigated flora species groups, the median of $78 \%$ indicates clearly higher mean species richness through organic farming (Table 3). For arable flora, the median for the organic variants was even higher (95\%), and only one comparison pair indicated a negative influence of organic farming in comparison to conventional farming. In 7 studies with 11 pairs, the data for arable flora were differentiated between the field edge and inside the field. The median inside the field was higher $(+304 \%$ for organic farming) in comparison to the field edge at $94 \%$. The organic variants showed higher species richness for seedbank (median 61\%) as well as for field margin flora (median 21\%), and no negative effects incurred through organic farming (Fig. 1, Table 3). The results of the comparison of organic and conventional variants with respect to the significances given in the studies are also presented in Table 3. In total, $85 \%$ of the pairs comparing flora species showed higher mean richness in organic farming. With regard to arable flora, $86 \%$ showed a higher mean richness with $62 \%$ significant results. Only one pair had higher species numbers in conventional farming. For seedbank and field margin flora, $83 \%$ and $71 \%$ of the pairs indicated positive effects through organic farming. 
Table 2 Classification of organic and conventional farming according to richness and abundance (mean and total) for selected species groups of flora and fauna ( $n=98$ studies, 474 pairs)

\begin{tabular}{|c|c|c|c|c|c|c|c|}
\hline \multirow[t]{2}{*}{ Species groups } & \multirow[t]{2}{*}{ Indicator } & & \multirow[t]{2}{*}{ Studies (n) } & \multirow[t]{2}{*}{ Pairwise comparisons (n) } & \multicolumn{3}{|c|}{ Amount (\%) and [pairwise comparisons (n)] with } \\
\hline & & & & & Org + & Org $=$ & Org - \\
\hline \multirow[t]{5}{*}{ Flora and fauna } & Richness & mean & 70 & 208 & $63[130 / 99 *]$ & $36[75]$ & $1[3 / 2 *]$ \\
\hline & Richness & total & 29 & 58 & $62[36 / 4 *]$ & $36[21]$ & $2[1 / 0 *]$ \\
\hline & Abundance & mean & 53 & 190 & $51[97 / 69 *]$ & $42[80]$ & $7\left[13 / 0^{*}\right]$ \\
\hline & Abundance & total & 11 & 18 & $67[12 / 0 *]$ & $33[6]$ & 0 \\
\hline & \multicolumn{2}{|c|}{ All indicators } & 98 & 474 & $58[275 / 172 *]$ & 38 [182] & $4[17 / 2 *]$ \\
\hline
\end{tabular}

$n$ number; * number of pairwise comparisons with significant values. If no significances are given, the results were classified based on a $20 \%$ deviation of the individual pairs of the organic from the conventional variant. Richness and abundance are higher (Org +), lower (Org -) in organic farming, or comparable to conventional farming $(\mathrm{Org}=)$

The investigations of the fauna showed more diverse results (Fig. 1, Table 3). Overall, the median for the fauna species indicates $22 \%$ higher species richness in organic farming (birds $35 \%$, insects $22 \%$, and spiders $15 \%)$. Extreme values were detected in particular for insects. The classification showed that a total of $40 \%$ of the fauna comparisons indicate a higher richness in organic farming with $28 \%$ significant results (Table 3). The positive effects were more obvious for birds and insects than for spiders, although negative effects only occurred for beetles. The total values for fauna are influenced mainly by the group of insects which represent $70 \%$ of the pairwise comparisons.

Mean species abundance is illustrated in Fig. 2 only for the fauna groups, as less than nine pairwise comparisons existed for the flora groups. Table 4 contains all investigated groups. About $100 \%$ of the pairwise comparisons for the flora and $47 \%$ for the fauna displayed positive effects through organic farming
(Table 4). The median indicates $148 \%$ greater abundance of plants (arable flora: 202\%) and $40 \%$ greater abundance of fauna individuals. All variants of the organic system were positive for the flora species, but it should be taken into account that only a few studies were available for this indicator (Table 4). For birds and bees, the median indicates higher mean abundance (24\% and 27\%), and these values for spiders, butterflies, and beetles showed a plus of more than $50 \%$. Similar to the indicator for mean richness, extreme values for mean abundance were detected in particular for insects. The proportion of pairs with no differences according to the classification was clearly larger in comparison to the flora.

Results concerning total richness and abundance are given comprehensively in Table 2, because there were fewer studies and comparison pairs for each species group. Overall, the results followed the same trend as for mean richness and abundance.
Fig. 1 Differences between organic and conventional farming for mean species richness of flora and fauna $(\mathrm{n}=$ number of pairwise comparisons). Positive values indicate a higher species richness in the organic variant $($ con $=0 \%)$. Extremes, arable flora 757,800 ; field margin flora 689; insects (total) 149 to 4880 ; bees 149 to 592 percent

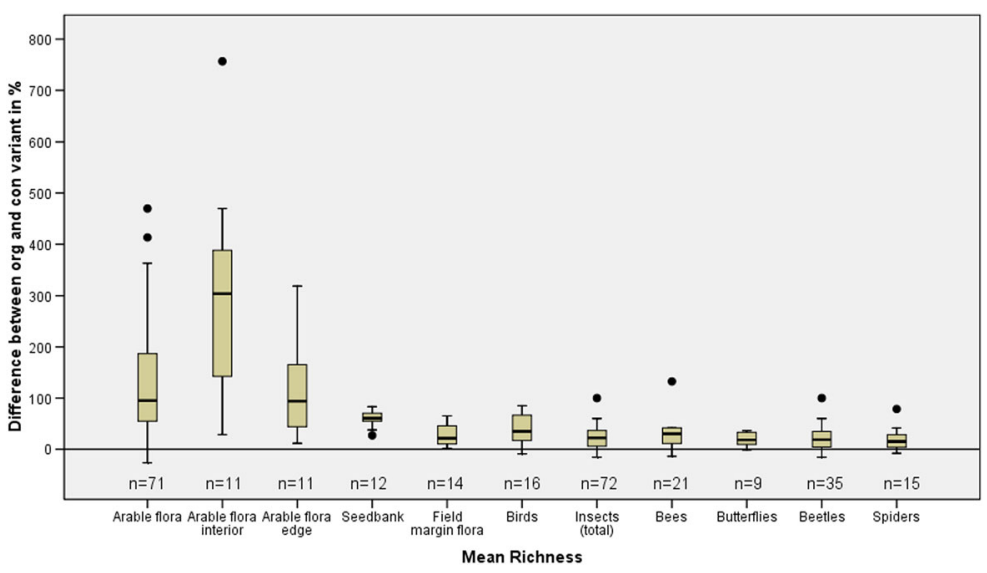


Table 3 Comparative data of organic and conventional farming showing mean richness for selected species groups of flora and aboveground fauna

\begin{tabular}{|c|c|c|c|c|c|c|c|c|c|c|}
\hline \multirow[t]{2}{*}{ Species groups } & \multirow[t]{2}{*}{ Studies (n) } & \multirow[t]{2}{*}{$\begin{array}{l}\text { Pairwise } \\
\text { comparisons (n) }\end{array}$} & \multicolumn{5}{|c|}{$\begin{array}{l}\text { Difference org vs. con }(\%) \\
\text { (mean richness org / } \\
\text { mean richness con }(\%)-100)\end{array}$} & \multicolumn{3}{|c|}{$\begin{array}{l}\text { Amount }(\%) \text { and } \\
\text { [pairwise comparisons (n)] with }\end{array}$} \\
\hline & & & Min & Q1 & Median & Q3 & Max & Org + & Org $=$ & Org - \\
\hline Arable flora & 29 & 71 & -27 & 51 & 95 & 193 & 800 & $86[61 / 44 *]$ & $13[9]$ & $1[1 / 0 *]$ \\
\hline interior & 7 & 11 & 28 & 83 & 304 & 413 & 757 & $91\left[10 / 6^{*}\right]$ & $9[1]$ & 0 \\
\hline edge & 7 & 11 & 12 & 43 & 94 & 181 & 318 & $91[10 / 5 *]$ & $9[1]$ & 0 \\
\hline Insect pollinated flora & 4 & 8 & 10 & 41 & 212 & 409 & 1051 & $100[8 / 8 *]$ & 0 & 0 \\
\hline Seedbank & 5 & 12 & 27 & 55 & 61 & 70 & 83 & $83[10 / 9 *]$ & 17 [2] & 0 \\
\hline Field margin flora & 8 & 14 & 1 & 10 & 21 & 46 & 689 & $71[10 / 9 *]$ & $29[4]$ & 0 \\
\hline Flora & 39 & 105 & -27 & 45 & 78 & 175 & 1051 & 85 [89/70*] & 14 [15] & $1[1 / 0 *]$ \\
\hline Birds & 10 & 16 & -9 & 17 & 35 & 66 & 85 & $69\left[11 / 11^{*}\right]$ & $31[5]$ & 0 \\
\hline Insects (total) & 30 & 72 & -16 & 6 & 22 & 38 & 4880 & 40 [29/17*] & $57[41]$ & $3[2 / 2 *]$ \\
\hline Bees & 10 & 21 & -14 & 11 & 30 & 42 & 592 & $43[9 / 7 *]$ & 57 [12] & 0 \\
\hline Butterflies & 6 & 9 & -1 & 9 & 18 & 33 & 36 & $44[4 / 2 *]$ & $56[5]$ & 0 \\
\hline Beetles & 15 & 35 & -16 & 4 & 19 & 38 & 100 & $40\left[14 / 6^{*}\right]$ & 54 [19] & $6[2 / 2 *]$ \\
\hline Spiders & 7 & 15 & -8 & 0 & 15 & 30 & 79 & 7 [1/1*] & 93 [14] & 0 \\
\hline Fauna & 40 & 103 & -16 & 7 & 22 & 39 & 4880 & $40[41 / 29 *]$ & $58[60]$ & $2[2 / 2 *]$ \\
\hline
\end{tabular}

$n$ number; * number of pairwise comparisons with significant values. If no significances are given, the results were classified based on a $20 \%$ deviation of the individual pairs of the organic from the conventional variant. Richness is higher (Org +), lower (Org -) in organic farming, or comparable to conventional farming $(\mathrm{Org}=)$

\section{Discussion}

The results show that organic farming clearly increased species richness and abundance of selected taxa of flora and aboveground fauna significantly. It confirms the results of former authors of the beneficial effects of organic farming on biodiversity (e.g., Tuck et al. 2014; Mondelaers et al. 2009; Rahmann 2011; Bengtsson et al. 2005; Hole et al. 2005). Tuck et al. (2014) determined an overall increase in species richness of about $30 \%$. As in our study, the effects differed between taxonomic groups. The value for arthropods in their study corresponds to our results for insects. The positive effects of organic farming on birds and arable flora were more pronounced in our investigation.

While organic farming is defined by national and even broader regulations such as the European Union standards (EC No 834/2007), no clear definition exists for conventional farming. The legal framework for organic farming offers essential preconditions for the survival of many species that live wholly or partly on agricultural land. As a result, direct positive effects (e.g., no use of synthetic pesticides) as well as indirect positive effects on wild flora and fauna species and their habitats can be assumed, e.g., the renunciation of mineral nitrogen fertilizers, the limitation on broughtin fodder and livestock units, the necessity of the integration of legumes in the rotation, and pest control using beneficial species. As a result of the limited level of fertilization, a lower plant density occurs which has beneficial effects on wild flora and fauna (Thies et al. 2010). The integration of legume-grassleys offers good habitat conditions for birds as well as insects (Stein-Bachinger and Fuchs 2012; SteinBachinger et al. 2010).

Impacts on flora

In line with previous studies, arable plants benefited most from organic farming (Tuck et al. 2014; Rahmann 2011; Bengtsson et al. 2005; Hole et al. 2005). The effect can presumably be attributed mostly 


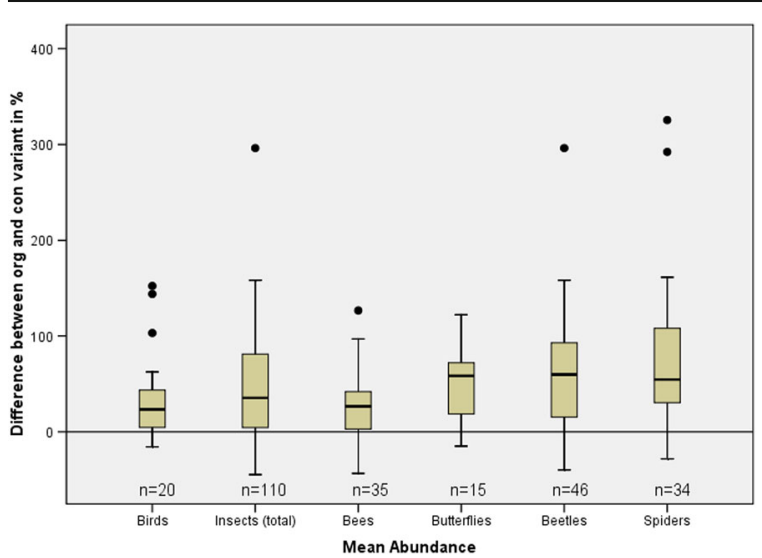

Fig. 2 Differences between organic and conventional farming for mean abundance of fauna species groups $(n=$ number of pairwise comparisons). Positive values indicate a higher species abundance in the organic variants (con $=0 \%$ ). Extremes, insects (total) 370 to 38,200 ; bees 370,603 ; spiders 343,386 precent

to the fact that no herbicides are used. Further reasons are the rotation practices and cultivation of own seeds (Chamorro et al. 2016) as well as the lower productivity of the crops (Shah et al. 2017; Thies et al. 2010) which implies light stands favoring less competitive species (Albrecht et al. 2016). As the intensification of conventional farming led to dramatic losses in flora biodiversity (Meyer et al. 2013), species under organic farming can recover from the seedbank or from sites at field edges (Chamorro et al. 2016). Nevertheless, this is not possible when the seedbank is depleted after a long period of intensive agriculture, which can be one reason for species' poor organic fields (Rotchés-Ribalta et al. 2015).

With regard to arable flora, only one comparison pair displayed negative effects in mean species richness in organic farming according to the $20 \%$ deviation (Knudsen et al. 2017). In this study, one conventional variant comprises very extensively cultivated fields with low fertilization and without pesticides. Renouncing pesticides does not generally correspond to common conventional farming methods, although there is no legal framework as mentioned above. Therefore, these pairs could have been eliminated from the evaluation. In line with Gabriel et al. (2010) and Batáry et al. (2012), the differences in plant diversity were much more pronounced within the fields. This can be explained by the

Table 4 Comparative data of organic and conventional farming showing mean abundance for selected species groups of flora and aboveground fauna

\begin{tabular}{|c|c|c|c|c|c|c|c|c|c|c|}
\hline \multirow[t]{2}{*}{ Species groups } & \multirow[t]{2}{*}{ Studies (n) } & \multirow[t]{2}{*}{$\begin{array}{l}\text { Pairwise } \\
\text { comparisons (n) }\end{array}$} & \multicolumn{5}{|c|}{$\begin{array}{l}\text { Difference org vs. con }(\%) \\
\text { (mean abundance org / } \\
\text { mean abundance con }(\%)-100 \text { ) }\end{array}$} & \multicolumn{3}{|c|}{$\begin{array}{l}\text { Amount }(\%) \text { and } \\
\text { [pairwise comparisons }(n) \text { ] with }\end{array}$} \\
\hline & & & Min & Q1 & Median & Q3 & Max & Org + & Org $=$ & Org - \\
\hline Arable flora & 5 & 7 & 113 & & 202 & & 1954 & $100[7 / 3 *]$ & 0 & 0 \\
\hline Seedbank & 2 & 6 & 103 & & 162 & & 245 & $100\left[6 / 6^{*}\right]$ & 0 & 0 \\
\hline Field margin flora & 1 & 2 & 29 & & 34 & & 39 & $100[2 / 2 *]$ & 0 & 0 \\
\hline Flora & 8 & 15 & 29 & 113 & 148 & 210 & 1954 & $100\left[15 / 11^{*}\right]$ & 0 & 0 \\
\hline Birds & 11 & 20 & -16 & 5 & 24 & 44 & 152 & $50[10 / 10 *]$ & $50[10]$ & 0 \\
\hline Skylark & 4 & 8 & -10 & 1 & 75 & 132 & 284 & $50[4 / 4 *]$ & $50[4]$ & 0 \\
\hline Insects (total) & 33 & $113^{\mathrm{a}}$ & -45 & 5 & 36 & 81 & 38,200 & $42[48 / 28 *]$ & $46[52]$ & $12\left[13 / 0^{*}\right]$ \\
\hline Bees & 10 & 35 & -44 & 3 & 27 & 43 & 603 & 37 [13/7*] & $51[18]$ & $11[4 / 0 *]$ \\
\hline Butterflies & 6 & 15 & -15 & 17 & 59 & 75 & 122 & $73[11 / 4 *]$ & $27[4]$ & 0 \\
\hline Beetles & 20 & $49^{\mathrm{a}}$ & -40 & 15 & 60 & 93 & 296 & $43\left[21 / 15^{*}\right)$ & $53[26]$ & $4[2 / 0 *]$ \\
\hline Spiders & 15 & 34 & -28 & 31 & 55 & 108 & 386 & $59\left[20 / 16^{*}\right]$ & 41 [14] & 0 \\
\hline Fauna & 47 & $175^{\mathrm{a}}$ & -45 & 7 & 40 & 86 & 38,200 & $47\left[82 / 58^{*}\right]$ & $46[80]$ & 7 [13/0*] \\
\hline
\end{tabular}

$n$ number; * number of pairwise comparisons with significant values. If no significances are given, the results were classified based on a $20 \%$ deviation of the individual pairs of the organic from the conventional variant. Abundance is higher (Org +), lower (Org -) in organic farming, or comparable to conventional farming $(\mathrm{Org}=)$

${ }^{\text {a }}$ Including three pairwise comparisons according to statistical remarks in Caro et al. (2016) for the classification 
fact that herbicide application usually affects the centers more than the edges (Metcalfe et al. 2019; Batáry et al. 2012; van Elsen 1989). Field edges can be safer sites for weeds. As a consequence, Roschewitz et al. (2005) found that the overall flora diversity in complex landscapes which include a large number of field edges can be high even in conventional farming systems. Even more than for the field edges, it is obvious that the effects of cropping systems are lower on field margins than on the fields themselves. But it is remarkable that predominantly significant positive effects of organic farming were found in these boundary structures, which implies that conventional farming also has negative effects on adjacent habitats in the landscape. Gabriel et al. (2010) demonstrated this effect on a larger scale: in landscapes with a high proportion of conventional farming, biodiversity was lower on organic farms than on organic farms situated in landscapes with a smaller part of conventionally managed fields. The more pronounced differences between organic and conventional farming with regard to the interior of fields implicate that the positive effect of organic farming is even larger with respect to the whole landscape area than the integrative consideration of all comparison pairs, because the inner fields cover much more area in the landscape than the field edges.

Impacts on fauna

The investigations on fauna species provide a more diverse picture. A higher number of the pairwise comparisons showed no differences in species richness and abundance between the farming systems and negative effects of organic farming. One reason could be that animals in general have a higher operating radius and can react more flexibly to changes in land use than plants. Moreover, many species of birds, insects, and spiders use cultivated fields only occasionally as a part of their habitat and depend greatly on the number and quality of landscape elements (Tuck et al. 2014; Winqvist et al. 2012; Gabriel et al. 2010; Tscharntke et al. 2005). Batary et al. (2010) found hedge length to be more significant for bird species richness than organic farming. Birds, such as the yellow wagtail (Motacilla flava), search for fodder for fledglings up to $1000 \mathrm{~m}$ away from their nests (Südbeck 2005). Therefore, they can breed on arable fields and simultaneously compensate the low food reserves on the fields by using adjacent habitats like field margins or grassland. In some investigations, these aspects are considered by including landscape structures in the evaluation or by choosing pairs in similar landscapes (e.g., Batáry et al. 2010; Gabriel et al. 2010). Nevertheless, Gabriel et al. (2010) explain the reasons for the variation in bird population in organic and conventional farming through differences in the landscape structures. In line with Holzschuh et al. (2007) and Roschewitz et al. (2005), they suggest that typical conventional farms would be larger and less mixed and that they might have also excluded the most intensive arable landscapes with even lower biodiversity levels. The pronounced extreme values for insects could be attributed to the overall high variation in population sizes, which complicates standardized comparison studies. Moreover, asynchronous fluctuations of insects in different investigation areas could strongly influence the results.

Implications for policy/management

Our review suggests that organic farming can be an effective management system to support biodiversity in agricultural landscapes and should be better promoted. Another important strategy is to combine the positive effects of organic farming with an adequate number of high quality landscape structures. For example, flower-visiting insects like solitary bees and bumble bees benefit from the rich flower resources in organic fields, but they also need nesting sites, e.g., on fallow strips or field margins. A combination of these habitats can largely enhance the species richness and density of these insects (Holzschuh et al. 2008). Likewise, field birds such as the linnet or yellowhammer are supported by the larger supply of seeds and insects in organic fields yet need hedges as breeding sites (Smith et al. 2010). Consequently, the maximum species richness can be achieved on organic farmland in richly structured landscapes (Batáry et al. 2017; Gabriel et al. 2010).

It can be assumed that the relationship between biodiversity and ecosystem services is not linear, as higher biodiversity does not necessarily lead to more ecosystem services being either produced or used (Tscharntke et al. 2005). However, it is possible to assume that higher levels of biodiversity strengthen the stability and resilience of ecosystems and of farming systems, respectively, and help to ensure the availability of ecosystem services (Di Falco 2012; Firbank 2005). Consequently, several ecosystem services can only be wholly or partly provided below a critical threshold value. Habel et al. (2019) and Gabriel et al. (2010) underline 
the urgent need for more biodiversity-friendly cultivation methods. As certain species cannot be protected by common farming operations but depend on land use, optimization strategies are necessary. In the last decade, many options of improving organic farming for biodiversity purposes have been investigated concentrating on selected fields or parts of fields with a high potential for special conservation goals, while most of the farm area can continue to be managed according to standard practice (Gottwald and Stein-Bachinger 2018; SteinBachinger and Fuchs 2012).

As heterogeneity in the landscape is a key factor influencing a large number of species, it is necessary to integrate a whole range of scientifically sound but also economically viable nature conservation measures into the farm business on a broader scale, including adjacent habitats on a landscape level. Above all, one important issue that needs to be taken into consideration is that organic farming can simultaneously reduce a number of environmental problems and, consequently, these aggregated positive impacts should also play an important role when evaluating organic farming (Sanders and Hess 2019, eds.).

One huge challenge will be the development and testing of new management concepts to increase the overall efficiency of the whole system, e.g., the optimization of yields and reduction in greenhouse gas emissions in relation to nutrient input and biodiversity issues. In this way, quantifying the precise benefits delivered by organic farming is essential and thus makes a significant contribution to solving current environmental and resource policy challenges. The task for politicians will be to implement a reward system that offers incentives for environmental achievements that are demanded by the society so that farmers do not only envisage themselves as producers of food but also as service providers for the biotic and esthetic functions of landscape.

\section{Implications for research}

We conclude that even more strict selection criteria are necessary concerning system representativeness in future reviews and meta-analyses to adequately reflect the different management systems. Some farms classified as "conventional" in the studies practice traditional and extensive farming with very low or zero fertilization and chemical pest control. This can be one reason for the positive effects of conventional farming in the comparative studies. The effects of organic farming also depend on the isolation of the managed fields. Investigations which take place on isolated fields, or farms with intensive farming in the surrounding area, cannot reflect the full potential of organic farming as these fields or farms can be considered to be habitat islands with lower species diversity (Kruess and Tscharntke 2000). This also leads to the question whether species diversity will be much more enhanced if organic farming is practiced on larger, continuous areas on a landscape scale.

Many studies compare organic and conventional farming based on single crops (mainly winter wheat) for reasons of homogenous study design. Nevertheless, in this way, the positive effects of organic farming relating, e.g., to higher crop diversity and the higher amount of legume-grass mixtures in the rotation cannot be detected. Thus the impacts and interactions need to be addressed not only for single measures or crops on a small number of fields but on the whole farm and landscape level. In addition, it would also be perceptive to investigate the influence of other factors such as the crop type and tillage system, the duration of organic management, the required number of landscape elements in the surrounding landscape, and the intensities of cropping systems in future research. Moreover, our systematic review identified only a few relevant studies for special species which means that more studies are necessary to enlarge the evidence base.

Acknowledgments We thank Prof. Dr. Thomas Döring for his valuable remarks during the writing of the report (Sanders and Hess 2019, eds.) which forms the basis for this publication as well as the whole project team.

Data accessibility All data are from published studies. A list of data sources is provided in the supplements.

Authors' contribution All authors participated in designing the review. KS led the writing of the manuscript; KS, AH, and FG designed the methodology and interpreted the data. AH and KS collected the data; AH and ES extracted and analyzed the data. All authors contributed critically to the drafts and gave their final approval for publication.

Funding information Open Access funding provided by Projekt DEAL. We thank the Federal Ministry of Food and Agriculture for the financial support within the Federal Organic Farming Scheme and other forms of Sustainable Farming Systems (BÖLN).

Open Access This article is licensed under a Creative Commons Attribution 4.0 International License, which permits use, sharing, 
adaptation, distribution and reproduction in any medium or format, as long as you give appropriate credit to the original author(s) and the source, provide a link to the Creative Commons licence, and indicate if changes were made. The images or other third party material in this article are included in the article's Creative Commons licence, unless indicated otherwise in a credit line to the material. If material is not included in the article's Creative Commons licence and your intended use is not permitted by statutory regulation or exceeds the permitted use, you will need to obtain permission directly from the copyright holder. To view a copy of this licence, visit http://creativecommons.org/licenses/by/4.0/.

\section{References}

Albrecht H, Cambecèdes J, Lang M, Wagner M (2016) Management options for the conservation of rare arable plants in Europe. Botany Letters 163:389-415. https://doi. org/10.1080/23818107.2016.1237886

Azeez G (2000) The biodiversity benefits of organic farming. Soil Association Ltd, Bristol, UK

Batáry P, Gallé R, Riesch F, Fischer C, Dormann CF, Mußhoff O, Császár P, Fusaro S, Gayer C, Happe AK, Kurucz K, Molnár D, Rösch V, Wietzke A, Tscharntke T (2017) The former iron curtain still drives biodiversity-profit trade-offs in German agriculture. Nat Ecol Evol 1:1279-1284. https://doi. org/10.1038/s41559-017-0272-x

Batáry P, Holzschuh A, Orci KM, Samu F, Tscharntke T (2012) Responses of plant, insect and spider biodiversity to local and landscape scale management intensity in cereal crops and grasslands. Agric Ecosyst Environ 146:130-136. https://doi. org/10.1016/j.agee.2011.10.018

Batáry P, Matthiesen T, Tscharntke T (2010) Landscapemoderated importance of hedges in conserving farmland bird diversity of organic vs. conventional croplands and grasslands. Biol Conserv 143:2020-2027. https://doi.org/10.1016 /j.biocon.2010.05.005

Bengtsson J, Ahnstrom J, Weibull AC (2005) The effects of organic agriculture on biodiversity and abundance: a metaanalysis. J Appl Ecol 42:261-269. https://doi.org/10.1111 j.1365-2664.2005.01005.x

Benton TG, Vickery JA, Wilson JD (2003) Farmland biodiversity: is habitat heterogeneity the key? Trends Ecol Evol, 18, 182188. https://doi.org/10.1016/s0169-5347(03)00011-9

Berg C, Dengler J, Abdank A, Isermann M (2004) Die Pflanzengesellschaften Mecklenburg-Vorpommerns und ihre Gefährdung - Textband. Weißdorn-Verlag, Jena

BMU (2018) Biologische Vielfalt in Deutschland. Bundesministerium für Umwelt, Naturschutz und nukleare Sicherheit Retrieved from https://www.bmu. de/fileadmin/Daten_BMU/Pools/Broschueren/biologische_ vielfalt_bf.pdf [accessed 14.12.2019]

Campiglia E, Radicetti E, Mancinelli R (2018) Floristic composition and species diversity of weed community after 10 years of different cropping systems and soil tillage in a Mediterranean environment. Weed Res 58:273-283. https://doi.org/10.1111/wre.12301
Caro G, Marrec R, Gauffre B, Roncoroni M, Augiron S, Bretagnolle V (2016) Multi-scale effects of agrienvironment schemes on carabid beetles in intensive farmland. Agric Ecosyst Environ 229:48-56. https://doi. org/10.1016/j.agee.2016.05.009

CBD (2000) Sustaining life on earth. Secretariat of the convention on biological diversity. Retrieved from https://www.cbd. int/doc/publications/cbd-sustain-en.pdf [accessed 05.08.2019]

Chamberlain DE, Wilson JD, Fuller RJ (1999) A comparison of bird populations on organic and conventional farm systems in southern Britain. Biol Conserv 88:307-320. https://doi. org/10.1016/s0006-3207(98)00124-4

Chamorro L, Masalles RM, Sans FX (2016) Arable weed decline in Northeast Spain: does organic farming recover functional biodiversity? Agric Ecosyst Environ 223:1-9. https://oi. org/10.1016/j.agee.2015.11.027

Di Falco S (2012) On the value of agricultural biodiversity. Ann Rev Resour Econ 4:207-223. https://doi.org/10.1146 /annurev-resource-110811-114543

Eglington S (2009) Understanding the causes of decline in breeding wetland bird numbers in England. BTO Report Research no. 562, pp. 124. British Trust for Ornithology. Retrieved from https://www.bto.org/sites/default/files/shared documents/publications/research-reports/2014/rr562.pdf [accessed 05.08.2019]

EUROSTAT (2018). Retrieved from https://ec.europa. eu/eurostat/de/web/lucas/data/primary-data/2018 [accessed 05.08.2019]

Fabian Y, Sandau N, Bruggisser OT, Aebi A, Kehrli P, Rohr RP, Naisbit RE, Bersier LF (2013) The importance of landscape and spatial structure for hymenopteran-based food webs in an agro-ecosystem. J Anim Ecol 82:1203-1214. https://doi. org/10.1111/1365-2656.12103

Firbank LG (2005) Striking a new balance between agricultural production and biodiversity. Ann Appl Biol 146:163-175. https://doi.org/10.1111/j.1744-7348.2005.040078.x

Flade M (2012) Von der Energiewende zum BiodiversitätsDesaster - zur Lage des Vogelschutzes in Deutschland. Vogelwelt 133:149-158

Frieben B (1990) Bedeutung des Organischen Landbaus für den Erhalt von Ackerwildkräutern. Natur und Landschaft 65: 379-382

Gabriel D, Sait SM, Hodgson JA, Schmutz U, Kunin WE, Benton TG (2010) Scale matters: the impact of organic farming on biodiversity at different spatial scales. Ecol Lett 13:858-869. https://doi.org/10.1111/j.1461-0248.2010.01481.x

Gottwald F, Stein-Bachinger K (2016) Landwirtschaft für Artenvielfalt - Ein Naturschutzmodul für ökologisch bewirtschaftete Betriebe. 208 p. https://www.landwirtschaftartenvielfalt.de/ [accessed 05.08.2019]

Gottwald F, Stein-Bachinger K (2018) 'Farming for biodiversity' a new model for integrating nature conservation achievements on organic farms in North-Eastern Germany. Org Agric 8:79-86. https://doi.org/10.1007/s13165-017-0198-2

Habel JC, Ulrich W, Biburger N, Seibold S, Schmitt T (2019) Agricultural intensification drives butterfly decline. Insect Conserv Diver, 0. https://doi.org/10.1111/icad.12343

Haber W (2014) Landwirtschaft und Naturschutz. Weinheim, Wiley-VCH Verlag 
Hald AB (1999) Weed vegetation (wild flora) of long established organic versus conventional cereal fields in Denmark. Ann Appl Biol 134:307-314. https://doi.org/10.1111/j.17447348.1999.tb05269.x

Hallmann CA, Sorg M, Jongejans E et al (2017) More than 75 percent decline over 27 years in total flying insect biomass in protected areas. PLoS One 12:21. https://doi.org/10.1371 /journal.pone.0185809

Heap I (2014) Herbicide resistant weeds. In: Pimentel D, Peshin R (eds) Integrated Pest management: pesticide problems. Springer Netherlands, Dordrecht, pp 281-301

Heldbjerg H, Fox AD, Levin G, Nyegaard T (2016) The decline of the starling Sturnus vulgaris in Denmark is related to changes in grassland extent and intensity of cattle grazing. Agric Ecosyst Environ 230:24-31 https://doi.org/10.1016/j. agee.2016.05.025

Herzon I, Ekroos J, Rintala J, Tiainen J, Seimola T, Vepsäläinen V (2011) Importance of set-aside for breeding birds of open farmland in Finland. Agric Ecosyst Environ 143:3-7. https://doi.org/10.1016/j.agee.2011.05.006

Hodgson JA, Kunin WE, Thomas CD, Benton TG, Gabriel D (2010) Comparing organic farming and land sparing: optimizing yield and butterfly populations at a landscape scale. Ecol Lett 13:1358-1367. https://doi.org/10.1111/j.14610248.2010.01528.x

Hole DG, Perkins AJ, Wilson JD, Alexander IH, Grice PV, Evans AD (2005) Does organic farming benefit biodiversity? Biol Conserv 122:113-130. https://doi.org/10.1016/j. biocon.2004.07.018

Holzschuh A, Steffan-Dewenter I, Kleijn D, Tscharntke T (2007) Diversity of flower-visiting bees in cereal fields: effects of farming system, landscape composition and regional context. J Appl Ecol 44:41-49. https://doi.org/10.1111/j.13652664.2006.01259.x

Holzschuh A, Steffan-Dewenter I, Tscharntke T (2008) Agricultural landscapes with organic crops support higher pollinator diversity. Oikos 117:354-361. https://doi. org/10.1111/j.2007.0030-1299.16303.x

Hooper DU, Adair EC, Cardinale BJ, Byrnes JEK, Hungate BA, Matulich KL, Gonzalez A, Duffy JE, Gamfeldt L, O'Connor MI (2012) A global synthesis reveals biodiversity loss as a major driver of ecosystem change. Nature 486:105-108. https://doi.org/10.1038/nature11118

Isbell F, Reich PB, Tilman D, Hobbie SE, Polasky S, Binder S (2013) Nutrient enrichment, biodiversity loss, and consequent declines in ecosystem productivity. Proceedings of the National Academy of Sciences, 110, 11911-11916. https://doi.org/10.1073/pnas.1310880110

Knudsen MT, Hermansen JE, Cederberg C et al (2017) Characterization factors for land use impacts on biodiversity in life cycle assessment based on direct measures of plant species richness in European farmland in the 'temperate broadleaf and mixed forest' biome. Sci Total Environ 580: 358-366. https://doi.org/10.1016/j.scitotenv.2016.11.172

Kottek M, Grieser J, Beck C, Rudolf B, Rubel F (2006) World map of the Köppen-Geiger climate classification updated. Meteorol Z 15:259-263. https://doi.org/10.1127/0941-2948 /2006/0130

Krauss J, Gallenberger I, Steffan-Dewenter I (2011) Decreased functional diversity and biological pest control in conventional compared to organic crop fields. PLoS One 6: 9. https://doi.org/10.1371/journal.pone.0019502

Kremen C, Williams NM, Thorp RW (2002) Crop pollination from native bees at risk from agricultural intensification. Proceedings of the National Academy of Sciences of the United States of America, 99, 16812-16816. https://doi. org/10.1073/pnas.262413599

Kruess A, Tscharntke T (2000) Effects of habitat fragmentation on plant-insect communities. In: Ekbom B, Irwin ME, Robert Y (eds) Interchanges of insects between agricultural and surrounding landscapes. Springer, Dordrecht, pp 53-70. https://doi.org/10.1007/978-94-017-1913-1_4

Landis DA (2017) Designing agricultural landscapes for biodiversity-based ecosystem services. Basic Appl Ecol 18: 1-12. https://doi.org/10.1016/j.baae.2016.07.005

Lichtenberg EM, Kennedy CM, Kremen C, Batáry P, Berendse F, Bommarco R, Bosque-Pérez NA, Carvalheiro LG, Snyder WE, Williams NM, Winfree R, Klatt BK, Åström S, Benjamin F, Brittain C, Chaplin-Kramer R, Clough Y, Danforth B, Diekötter T, Eigenbrode SD, Ekroos J, Elle E, Freitas BM, Fukuda Y, Gaines-Day HR, Grab H, Gratton C, Holzschuh A, Isaacs R, Isaia M, Jha S, Jonason D, Jones VP, Klein AM, Krauss J, Letourneau DK, Macfadyen S, Mallinger RE, Martin EA, Martinez E, Memmott J, Morandin L, Neame L, Otieno M, Park MG, Pfiffner L, Pocock MJO, Ponce C, Potts SG, Poveda K, Ramos M, Rosenheim JA, Rundlöf M, Sardiñas H, Saunders ME, Schon NL, Sciligo AR, Sidhu CS, Steffan-Dewenter I, Tscharntke T, Veselý M, Weisser WW, Wilson JK, Crowder DW (2017) A global synthesis of the effects of diversified farming systems on arthropod diversity within fields and across agricultural landscapes. Glob Chang Biol 23:49464957. https://doi.org/10.1111/gcb.13714

Lokemoen JT, Beiser JA (1997) Bird use and nesting in conventional, minimum-tillage, and organic cropland. J Wildl Manag 61:644-655. https://doi.org/10.2307/3802172

Lori M, Symnaczik S, Mäder P, De Deyn G, Gattinger A (2017) Organic farming enhances soil microbial abundance and activity - a meta-analysis and meta-regression. PLoS One 12:e0180442. https://doi.org/10.1371/journal.pone.0180442

McCracken DI, Tallowin JR (2004) Swards and structure: the interactions between farming practices and bird food resources in lowland grasslands. Ibis 146:108-114. https://doi.org/10.1111/j.1474-919X.2004.00360.x

Meehan TD, Werling BP, Landis DA, Gratton C (2011) Agricultural landscape simplification and insecticide use in the Midwestern United States. Proceedings of the National Academy of Sciences, 108, 11500-11505. https://doi. org/10.1073/pnas.1100751108

Metcalfe H, Hassall KL, Boinot S, Storkey J (2019) The contribution of spatial mass effects to plant diversity in arable fields. J Appl Ecol 56:1560-1574. https://doi.org/10.1111 /1365-2664.13414

Meyer S, Wesche K, Krause B, Leuschner C (2013) Dramatic losses of specialist arable plants in Central Germany since the 1950s/60s - a cross-regional analysis. Divers Distrib 19, 1175-1187. https:///doi/epdf/https://doi.org/10.1111 /ddi.12102

Mondelaers K, Aertsens J, Van Huylenbroeck G (2009) A metaanalysis of the differences in environmental impacts between 
organic and conventional farming. Br Food J 111:10981119. https://doi.org/10.1108/00070700910992925

Newbold T, Hudson LN, Arnell AP, Contu S, de Palma A, Ferrier S, Hill SL, Hoskins AJ, Lysenko I, Phillips HR, Burton VJ, Chng CW, Emerson S, Gao D, Pask-Hale G, Hutton J, Jung M, Sanchez-Ortiz K, Simmons BI, Whitmee S, Zhang H, Scharlemann JP, Purvis A (2016) Has land use pushed terrestrial biodiversity beyond the planetary boundary? A global assessment. Science 353:288-291. https://doi.org/10.1126 /science.aaf2201

Pe'er G, Lakner S, Müller R et al (2017) Is the CAP fit for purpose? An evidence based fitness-check assessment. German Centre for Integrative Biodiversity Research (iDiv) Halle - Jena - Leipzig, Leipzig

Pimm SL, Jenkins CN, Abell R et al (2014) The biodiversity of species and their rates of extinction, distribution, and protection. Science 344. https://doi.org/10.1126/science.1246752

Quinn JE, Awada T, Trindade F, Fulginiti L, Perrin R (2016) Combining habitat loss and agricultural intensification improves our understanding of drivers of change in avian abundance in a north American cropland anthrome. Ecol Evol 7: 803-814. https://doi.org/10.1002/ece3.2670

Rahmann G (2011) Biodiversity and organic farming: what do we know? Landbauforschung 61:189-208

Robinson RA, Sutherland WJ (2002) Post-war changes in arable farming and biodiversity in Great Britain. J Appl Ecol 39: 157-176. https://doi.org/10.1046/j.1365-2664.2002.00695.x

Rohatgi A (2018) WebPlotDigitizer. Version 3.8 Retrieved from https://automeris.io/WebPlotDigitizer

Roschewitz I, Gabriel D, Tscharntke T, Thies C (2005) The effects of landscape complexity on arable weed species diversity in organic and conventional farming. J Appl Ecol 42:873-882. https://doi.org/10.1111/j.1365-2664.2005.01072.x

Rotchés-Ribalta R, Blanco-Moreno JM, Armengot L, Chamorro L, Sans FX (2015) Both farming practices and landscape characteristics determine the diversity of characteristic and rare arable weeds in organically managed fields. Appl Veg Sci 18:423-431. https://doi.org/10.1111/avsc. 12154

Rydberg NT, Milberg P (2000) A survey of weeds in organic farming in Sweden. Biol Agric Hortic 18:175-185. https://doi.org/10.1080/01448765.2000.9754878

Sanders J, Hess J (eds) (2019) Leistungen des ökologischen Landbaus für Umwelt und Gesellschaft. Thünen Report, Johann Heinrich von Thünen-Institut, Braunschweig, 364 p. https://doi.org/10.3220/REP1547040572000

Seufert V, Ramankutty N (2017) Many shades of gray-the context-dependent performance of organic agriculture. Sci Adv 3. https://doi.org/10.1126/sciadv. 1602638

Shah A, Askegaard M, Rasmussen IA, Jimenez EMC, Olesen JE (2017) Productivity of organic and conventional arable cropping systems in long-term experiments in Denmark. Eur J Agron 90:12-22. https://doi.org/10.1016/j. eja.2017.07.001

Smith HG, Dänhardt J, Lindström Å, Rundlöf M (2010) Consequences of organic farming and landscape heterogeneity for species richness and abundance of farmland birds. Oecologia 162:1071-1079. https://doi.org/10.1007/s00442010-1588-2
Stein-Bachinger K, Fuchs S (2012) Protection strategies for farmland birds in legume-grass leys as trade-offs between nature conservation and farmers' needs. Org Agric 2:145-162. https://doi.org/10.1007/s13165-012-0029-4

Stein-Bachinger K, Fuchs S, Gottwald, F et al (2010) Naturschutzfachliche Optimierung des ökologischen Landbaus. Ergebnisse des E+E-Projektes "Naturschutzhof Brodowin". Naturschutz und Biologische Vielfalt 90. Bonn - Bad Godesberg. www.bfn.de. 409 p

Stoeckli S, Birrer S, Zellweger-Fischer J, Balmer O, Jenny M, Pfiffner L (2017) Quantifying the extent to which farmers can influence biodiversity on their farms. Agric Ecosyst Environ 237:224-233. https://doi.org/10.1016/j.agee.2016.12.029

Stolze M, Piorr A, Häring A, Dabbert S (2000) The environmental impacts of organic farming in Europe. Organic Farming in Europe: Economics and Policy Stuttgart-Hohenheim

Südbeck P (2005) Methodenstandards zur Erfassung der Brutvögel Deutschlands. Radolfzell

Thies C, Schreiber J, Flohre A, Fischer C, Tscharntke T (2010) Diversität, Produktivität und landwirtschaftliche Intensivierung. In Hotes S, Wolters V (Eds.) Fokus Biodiversität. Wie Biodiversität in der Kulturlandschaft erhalten und nachhaltig genutzt werden kann. Oekom Verlag, München. 171-175

Tscharntke T, Batáry P, Dormann CF (2011) Set-aside management: how do succession, sowing patterns and landscape context affect biodiversity? Agric Ecosyst Environ 143:3744. https://doi.org/10.1016/j.agee.2010.11.025

Tscharntke T, Klein AM, Kruess A, Steffan-Dewenter I, Thies C (2005) Landscape perspectives on agricultural intensification and biodiversity - ecosystem service management. Ecol Lett 8:857-874. https://doi.org/10.1111/j.1461-0248.2005.00782. $\mathrm{X}$

Tuck SL, Winqvist C, Mota F, Ahnström J, Turnbull LA, Bengtsson J (2014) Land-use intensity and the effects of organic farming on biodiversity: a hierarchical meta-analysis. J Appl Ecol 51:746-755. https://doi.org/10.1111/13652664.12219

Uchida K, Ushimaru A (2014) Biodiversity declines due to abandonment and intensification of agricultural lands: patterns and mechanisms. Ecol Monogr 84:637-658. https://doi. org/10.1890/13-2170.1

van Elsen T (1989) Ackerwildkraut-Gesellschaften herbizidfreier Ackerränder und des herbzidbehandelten Bestandesinneren im Vergleich. Tuexenia 9:75-105

Wahl J, Dröschmeister R, Gerlach B, Grüneberg C, Langgemach T, Trautmann S, Sudfeldt C (2015) Vögel in Deutschland 2014. DDA, BfN \& L. VSW, Münster

Winqvist C, Ahnström J, Bengtsson J (2012) Effects of organic farming on biodiversity and ecosystem services: taking landscape complexity into account. Ann N Y Acad Sci 1249:191203

Publisher's note Springer Nature remains neutral with regard to jurisdictional claims in published maps and institutional affiliations. 